\title{
Pathophysiological responses to meals in the Zollinger-Ellison syndrome: 2. Gastric emptying and its effect on duodenal function*
}

\author{
J-R MALAGELADA† \\ From the Gastroenterology Unit, Mayo Clinic and Mayo Foundation, Rochester, MN, USA
}

SUMMARY In this study, wc investigated the relationship between gastric emptying and duodenal events in patients with the Zollinger-Ellison syndrome due to a gastrinoma. Like the inhibitory effect of a meal on gastric secretion (described in a companion paper), postprandial inhibition of gastric emptying reduces fractional gastric emptying rates to normal during the first two hours after a meal. Gastric discharges of content into the duodenum fluctuate considerably, and, in some patients, duodenal acid load and neutralising duodenal secretions appear to be incoordinated. These mechanisms interact in part as a protective system that maintains reasonably normal duodenal homeostasis in most Zollinger-Ellison patients during the early postprandial period. Our data may explain why clinical evidence of overt-malabsorption is less prevalent and severe in these patients than would be expected from their enormously increased fasting gastric secretory outpuis.

Diarrhoea and steatorrhoea are common features of the Zollinger-Ellison syndrome and sometimes its only clinical manifestations. It is generally assumed that they result from the alteration in intraluminal digestion in the upper gut caused by gastric emptying of large volumes of highly acidic gastric juice. Moreover, several specific disturbances have been identified-among others, acid inactivation of pancreatic enzymes, precipitation of unionised bile acids, dilution of duodenal contents, and, possibly, damage to the intestinal mucosa. ${ }^{1-6}$

In spite of the progress made, our knowledge of digestive disturbances in the Zollinger-Ellison syndrome is still fragmentary and incomplete because (1) only isolated cases of the syndrome have been studied by any group of investigators, and these case reports do not indicate whether the abnormalities observed are exceptional or the rule; (2) most of the measurements have been of concentrations of either endogenously secreted or ingested substances without quantification of intraluminal flow or total secretory outputs; and (3) gastric emptying

\footnotetext{
*Supported in part by Grant AM-6908 from the National Institutes of Health.

†Address for reprint requests: Dr J-R Malagelada, Gastroenterology Unit, Mayo Clinic, Rochester, MN 55901 USA.

Received for publication 10 August 1979
}

of meal and gastric juice, presumably a key pathogenetic factor, has not been quantified.

In the first paper of this series ${ }^{7}$ we showed that profound variations of gastric secretory output occur postprandially in patients with gastrinoma. Thus, it cannot be assumed that the conventional basal acid output or maximal acid output measurements also represent the secretory output after a meal or, even less so, the postprandial rate of acid delivery into the duodenum. Using intubation and perfusion techniques developed in our laboratory, we evaluated, in an integrated fashion, the effects of postprandial gastric emptying on pancreatic, biliary, and intestinal function. Our goal has been to improve our understanding of the mechanisms of disturbed intraluminal digestion and diarrhoea in patients with the Zollinger-Ellison syndrome.

\section{Methods}

PATIENTS

Six patients (two females and four males, aged 13 to 63 years, with a mean of $40 \cdot 1$ years) with the Zollinger-Ellison syndrome were studied. All fulfilled the criteria of fasting gastric hyperchlorhydria, hypergastrinaemia, and, later, surgically proved gastrinoma. All were normocalcaemic, and none had had gastric surgery before studies were performed. Individual clinical histories and gastric 
secretory data were reported in the first paper of this series. ${ }^{7}$ Two patients were restudied after successful excision of their gastrinomas (duodenal wall tumour in both instances) without other surgical procedures. Six healthy volunteers (two women and four men, aged 22 to 63 years, with a mean of $39 \cdot 7 \pm 7 \cdot 1$ years) were similarly studied as controls.

\section{QUANTIFICATION OF POSTPRANDIAL GASTRIC} EMPTYING, PANCREATIC AND BILIARY

SECRETION, AND INTESTINAL FLOW

We used our methods for the quantification of gastric secretory outputs, gastric emptying of meal and secretions, pancreatic enzyme and biliary outputs, and total duodenal flow ${ }^{8-10}$. In the first paper of this series ${ }^{7} \mathrm{I}$ have described the pertinent methodological details. In addition, intestinal samples were analysed for $\mathrm{pH}$, osmolality, trypsin and lipase activities, and total bile acids by methods also previously described.$^{8-10}$ In previously reported studies $^{11}$ we showed that the presence of the transduodenal tube does not significantly alter the rate of gastric emptying. Two patients whose tumours were resected and whose fasting serum gastrin levels returned to normal after the procedure were restudied after the fourth postoperative week.

\section{Results}

GASTRIC EMPTYING (Fig. 1)

During the first postprandial hour, the total volume of gastric contents (meal and gastric secretion) emptied into the duodenum was similar in healthy controls and in patients with Zollinger-Ellison syndrome. Thereafter, the volume emptied gradually decreased in the healthy persons but continued increasing in the patients. By the third postprandial hour, gastric juice in the patients was being delivered into the duodenum at rates (about $600 \mathrm{ml} / \mathrm{h}$, as an average) similar to those of their fasting gastric secretory output ${ }^{7}$, an indication that the steadystate conditions between gastric secretion and emptying that prevail in the interdigestive period had returned. At that time, three hours after the meal, intragastric volume was similar in healthy persons in Zollinger-Ellison patients despite quite different emptying rates. This discrepancy is reflected in the fractional gastric emptying rate-that is, the percentage of intragastric contents emptied per unit of time. Fractional gastric emptying was similar in Zollinger-Ellison patients and in healthy persons during the first two postprandial hours but during the third hour it was significantly higher in the former $(P<0.05)$.

\section{FLOW AT LIGAMENT OF TREITZ AND ITS}

RELATIONSHIP TO GASTRIC EMPTYING

Intraluminal flow measured at the ligament of Treitz represents the net volume load (gastric emptying plus pancreatic, biliary, and duodenal secretions minus duodenal absorption) delivered into the jejunum. Flow profiles (Fig. 2) in ZollingerEllison patients were quite different from those in healthy controls. The highest flow rates in the healthy persons were reached during the first postprandial hour, whereas just the opposite was observed in the Zollinger-Ellison patients. During the second and third hours, flow rates were much higher in the patients than in the controls $(\mathrm{P}<0.05)$.

The influence of gastric emptying on jejunal volume loads in the Zollinger-Ellison syndrome can be appreciated in Fig. 3, where we have compared, in each individual, the volume delivered by the stomach during the three-hour observation period with the volume passing the ligament of Treitz during the same period. It is apparent that gastric
HEALTH

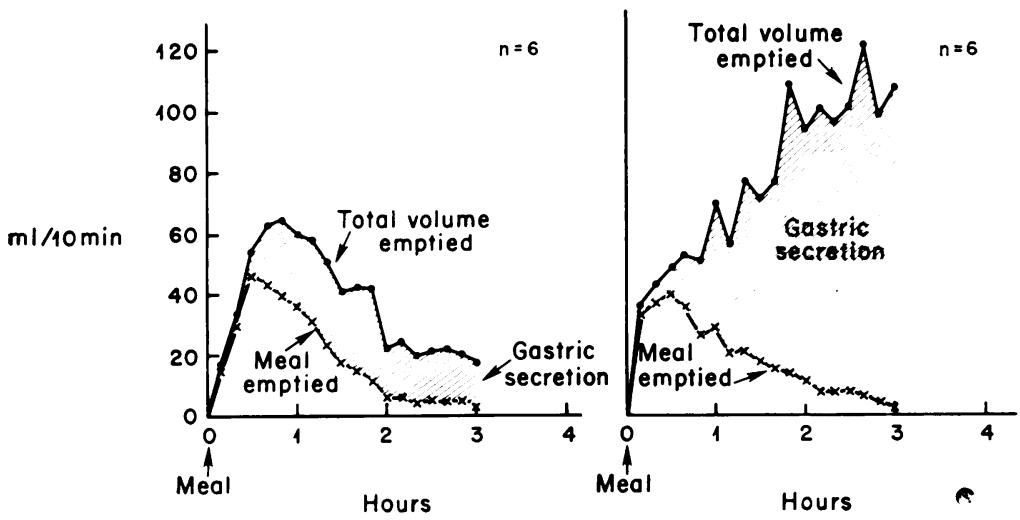

Fig. 1 Total volume of gastric contents empticd into duodenum after meals, including meal itself (clear area) and added gastric secretion (shaded area). Mean values every 10 minutes are given for healthy controls (left panel) and for patients with ZollingerEllison syndrome (right panel). 


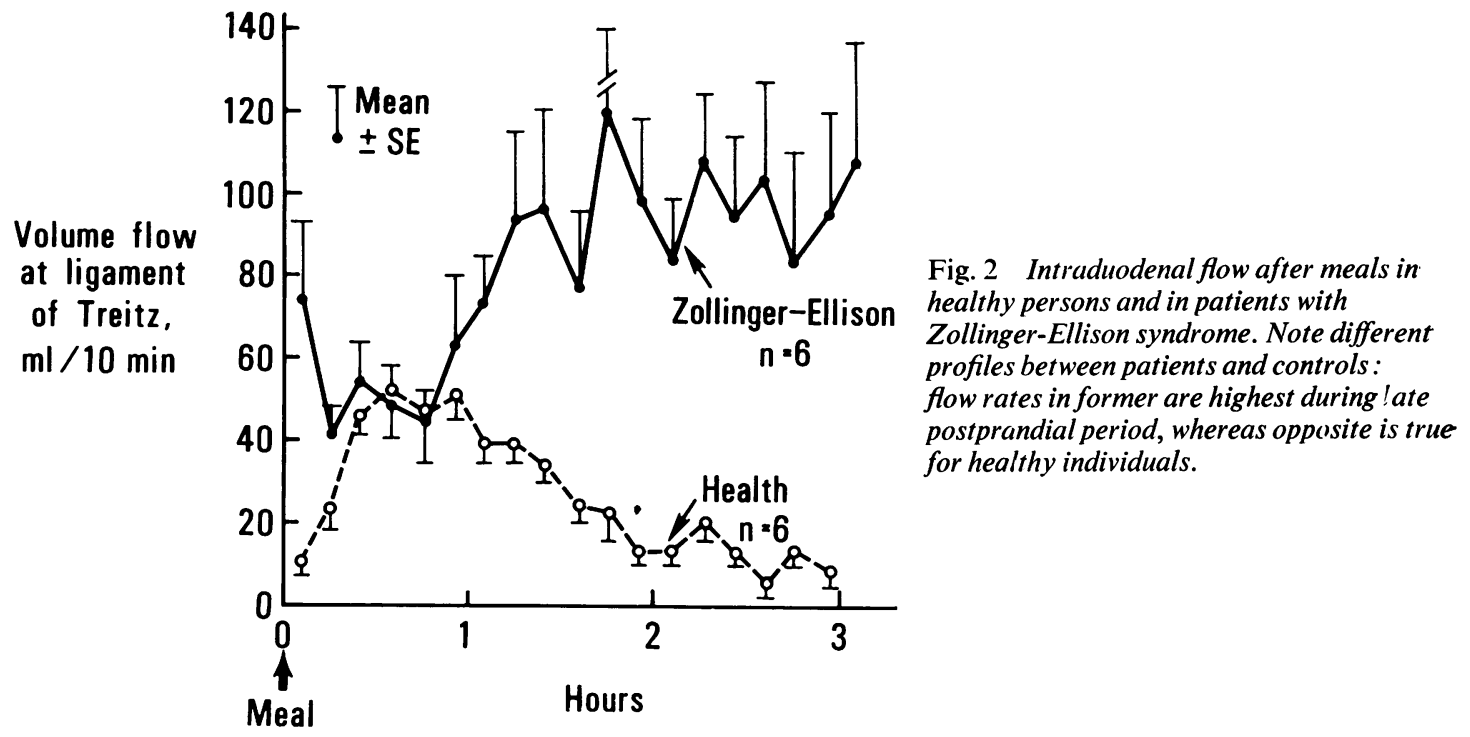

emptying is a major determinant of jejunal volume load in these patients with Zollinger-Ellison syndrome. This is so because duodenal absorption cannot increase enough to compensate for increased fluid emptied and, consequently, flow at the ligament of Treitz increases linearly with the absolute rate of gastric emptying. In two patients restudied after successful excision of their gastrin-producing

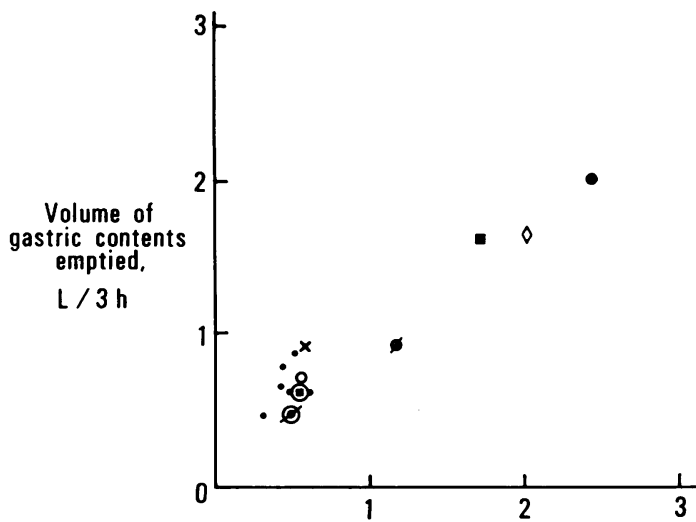

Volume flow at ligament of Treitz, L/3 h

Fig. 3 Relationship between gastric emptying and intraduodenal $f(0 w$ after meals in patients with ZollingerEllison syndrome and in healthy controls. Each patient is identified by a different symbol. A symbol enclosed in a circle indicates postoperative study. Healthy controls are represented by six identical small dots. Note that patients detached from control group form linear relationship between two measurements compared. After surgical removal of gastrinoma, their values approximate control.
Table 1 Peak postprandial outputs of pancreatic enzymes and bile acids

\begin{tabular}{|c|c|c|c|}
\hline \multirow{2}{*}{$\begin{array}{l}\text { Patients } \\
\text { with } \\
Z-E\end{array}$} & \multicolumn{3}{|c|}{ Peak output* } \\
\hline & $\begin{array}{l}\text { Trypsin } \\
(k U / \min )\end{array}$ & $\begin{array}{l}\text { Lipase, } \\
(k U / \min )\end{array}$ & $\begin{array}{l}\text { Bile acids } \\
\text { ( } \mu \text { mol/min) }\end{array}$ \\
\hline 1 & 596 & 2163 & $97 \cdot 1$ \\
\hline 2 & 831 & 3432 & $81 \cdot 3$ \\
\hline 3 & 1269 & 1659 & $79 \cdot 3$ \\
\hline 4 & 1004 & 4387 & 53.0 \\
\hline 5 & 494 & 1363 & $38 \cdot 1$ \\
\hline 6 & 457 & 1397 & $45 \cdot 3$ \\
\hline Mean $\pm S E$ & $775 \pm 131$ & $2400 \pm 507$ & $65 \cdot 7 \pm 9 \cdot 6$ \\
\hline $1+$ & 380 & 2574 & $48 \cdot 7$ \\
\hline $2+$ & 1232 & 4425 & $42 \cdot 5$ \\
\hline $\begin{array}{l}\text { Mean } \pm S E \\
\text { in } 6 \\
\text { healthy persons }\end{array}$ & $942 \pm 107$ & $2503 \pm 283$ & $53 \cdot 0 \pm 5 \cdot 6$ \\
\hline
\end{tabular}

*Highest three consecutive 10-minute periods.

† Repeat studies after excision of gastrin producing tumour.

Table 2 Effect of excision of gastrinoma on postprandial duodenal events

\begin{tabular}{|c|c|c|c|c|}
\hline \multirow[b]{2}{*}{ Measurement } & \multicolumn{2}{|c|}{ Patient 1} & \multicolumn{2}{|c|}{ Patient 2} \\
\hline & Preop & Postop & Preop & Postop \\
\hline Lowest duodenal pH & $3 \cdot 2$ & $4 \cdot 7$ & $2 \cdot 2$ & $4 \cdot 7$ \\
\hline Total minutes duodenal $\mathrm{pH}<4 \cdot 0$ & 40 & $\mathbf{0}$ & 90 & 0 \\
\hline $\begin{array}{l}\text { Lowest trypsin concentration } \\
(\mathrm{U} / \mathrm{ml})\end{array}$ & 25 & 58 & 21 & 119 \\
\hline $\begin{array}{l}\text { Lowest lipase concentration } \\
(\mathrm{U} / \mathrm{ml}) \\
\text { Lowest bile acid concentration }\end{array}$ & 10 & 381 & 1 & 532 \\
\hline $\begin{array}{l}\text { (mM) } \\
\text { Total minutes duodenal bile }\end{array}$ & $1 \cdot 1$ & $4 \cdot 0$ & $1 \cdot 1$ & 3.9 \\
\hline acid concentration $\pm 2.0 \mathrm{mM}^{*}$ & 10 & $\mathbf{0}$ & 30 & 0 \\
\hline
\end{tabular}

*Critical micellar concentration. 


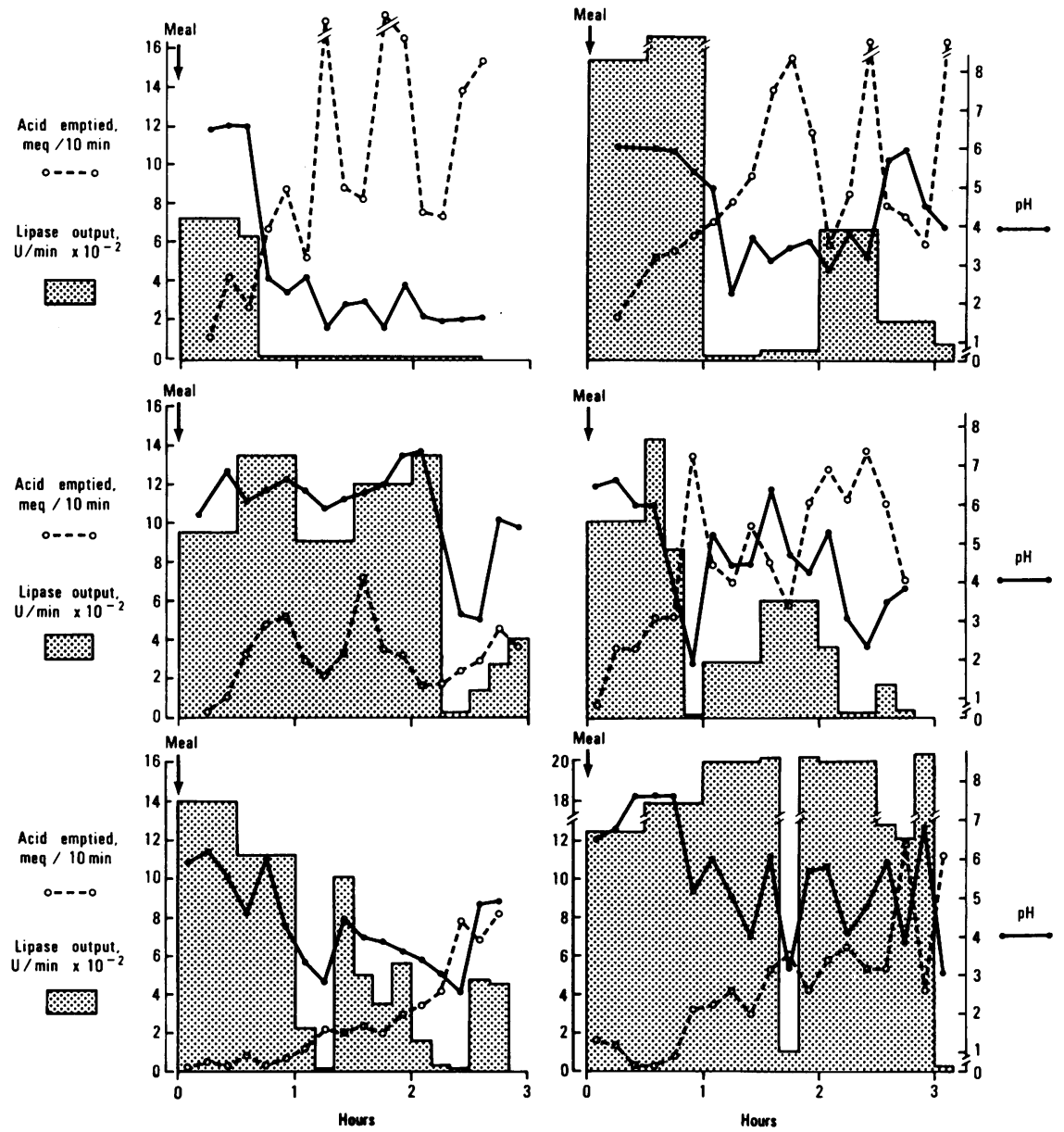

Fig. 4 Simultaneous postprandial measurements of gastric acid emptied (duodenal acid load), distal duodenal $\mathrm{pH}$, and total lipase activity for each of six patients with Zollinger-Ellison syndrome.

tumours, gastric emptying and intestinal flow returned to their normal relationship (Fig. 3).

\section{RATES OF ACID DELIVERY INTO DUODENUM} AND THEIR EFFECTS ON INTRALUMINAL PH, PANCREATIC ENZYME ACTIVITY, AND BILE ACID CONCENTRATION

In each patient, we measured simultaneously the postprandial rate of acid delivery into the duodenum and its effects on $\mathrm{pH}$ and lipase activity at the ligament of Treitz (Fig. 4). Almost invariably, we observed a gradual increase in duodenal acid load during the first 60 to 90 minutes and then wide fluctuations caused by intermittent gushes of secretion emptied by the stomach. Frequently, rapid increases in duodenal acid load were associated with a marked decrease in duodenal $\mathrm{pH}$. In some instances, there was no apparent relationship between these two measurements, perhaps a reflection of incoordination between acid delivery and duodenal acid-neutralising mechanisms.

Peak postprandial enzyme outputs (Table 1) were normal, an indication that both pancreatic function and responsiveness of regulatory mechanisms to the stimulus provided by the meal were normal. Invariably, a decrease in duodenal $\mathrm{pH}$ below 4.0 was associated with an abrupt decrease in lipase activity (net lipase output). Duration of acidinactivation periods varied considerably among patients (Fig. 4). In some, the duration was only 10 to 20 minutes, whereas, in others, inactivation lasted almost the entire three-hour postprandial observation period. Concentrations of intraluminal trypsin, lipase, and bile acid were also measured 


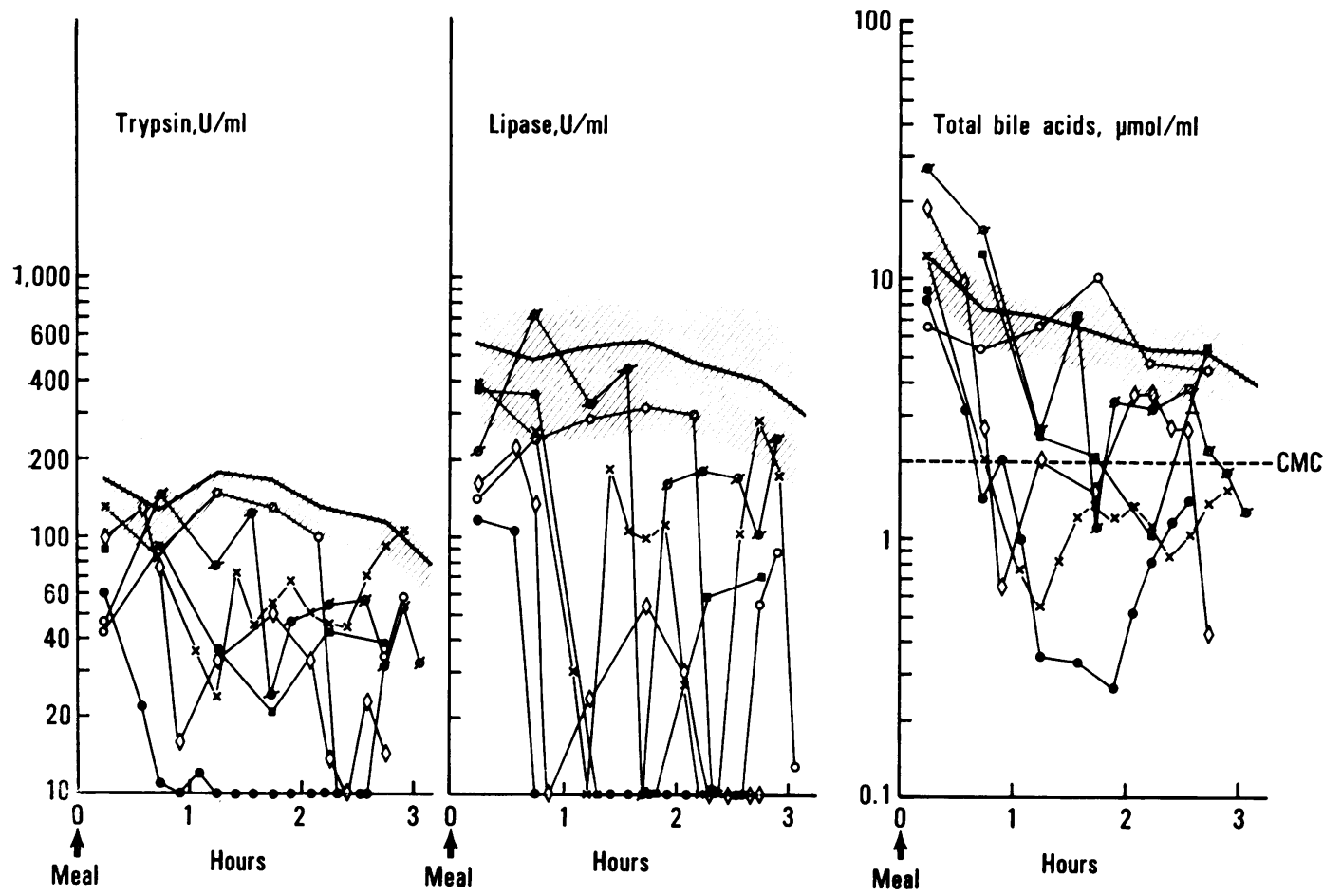

Fig. 5 Concentrations of intraduodenal trypsin, lipase, and bile acids after meals in healthy persons and in patients with Zollinger-Ellison syndrome. Mean and range for healthy controls are illustrated by shaded area. Values for each patient are represented (symbols match those in Fig. 3) and connected by lines. Dotted horizontal line on extreme right panel indicates critical micellar concentration $(2 \mathrm{mM})$.

(Fig. 5) to reveal the added pathogenetic effect of excessive dilution of intraduodenal contents by gastric secretion. Concentrations of both trypsin and lipase were frequently below the normal ranges and, during the second and third hours, lipase concentrations often decreased to less than $10 \%$ of normal, a critical limit for the development of steatorrhoea. ${ }^{12}$ Bile acid concentrations were temporarily reduced to less than $2 \mathrm{mM}$ (critical micellar concentration) in five of the six patients studied (Fig. 5). Correction of the abnormalities described followed the successful excision of a single duodenal gastrinoma in two of the patients (Table 2).

\section{Discussion}

In the first paper of this series, I showed that high gastric secretory outputs in patients with gastrinoma were temporarily inhibited by ingestion of a mixed meal, even though their hypergastrinaemia remained unchanged. ${ }^{7}$ It appeared, therefore, that the meal or some of its components temporarily counteracted the stimulatory effect of hypergastrinaemia on gastric secretion, adjusting it to a more nearly normal level. In this paper, I describe the events in the proximal small bowel, relating gastric emptying of meal and secretions to changes in intraluminal $\mathrm{pH}$, concentrations of pancreatic enzyme or bile acid, and intestinal flow.

It is well established that diarrhoea in the Zollinger-Ellison syndrome is related to gastric hypersecretion, as continuous aspiration of gastric juice and $\mathrm{H}_{2}$-receptor antagonists reduces it or even abolishes it $^{2}, 3,13,14$. Further, many potential pathogenetic mechanisms of this diarrhoea have been enumerated, including dilution of luminal contents, acid-inactivation of pancreatic enzymes, precipitation of bile acids, and alterations of mucosa. ${ }^{1-6,13}$ What is not known are the dynamics of the stomachsmall bowel interaction, as no simultaneous quantification of postprandial gastric emptying and duodenal events has previously been reported.

In a recent study in three patients with ZollingerEllison syndrome, Dubois et al. ${ }^{15}$ showed a raised fractional gastric emptying that was unchanged by intragastric instillation of a water load. As a group, the patients reported on here also exhibited a high fractional gastric emptying but only later in the 
postprandial period, when most ingested nutrients had already left the stomach. On the basis of these observations, we may conclude that the meal not only temporarily inhibited gastric secretion but also corrected abnormally high fractional gastric emptying. It should not come as a surprise that these meal-induced effects occur during the early postprandial period, for we have shown that physiologically, both the stimulatory and the inhibitory effects of the intestinal phase of gastric secretion and emptying also occur during the first hour after a meal. ${ }^{16,17}$

This apparent 'brake' effect of the meal on gastric secretion and emptying had repercussions distal to the pylorus, because most patients had a surprisingly gradual increase in gastric acid and volume delivery into the duodenum. In fact, during the first postprandial hour, sharp drops in luminal $\mathrm{pH}$ did not occur, concentrations of pancreatic enzyme and bile acid remained relatively normal, and luminal flow at the angle of Treitz actually decreased. Although fasting duodenal or jejunal $\mathrm{pH}$ has been measured in several reported cases ${ }^{1,3,5}$, only rarely has it been measured after a meal. Go et al.$^{6}$ reported performing postprandial determinations in a patient; as in our patients, the duodenal $\mathrm{pH}$ did not begin decreasing sharply until the end of the first postprandial hour. It should be emphasised that the buffering capacity of the meal itself is too small (40.1 meq for our meal) to account for this delay were it not helped by the postprandial decline in gastric secretion and emptying that we have shown.

The magnitude of the reduction in duodenal acid and volume load caused by the meal in ZollingerEllison patients is better appreciated by comparing duodenal loads during the first postprandial hour with those during the third hour, when the inhibitory effect of nutrients (on gastric secretion) had virtually disappeared in most patients. ${ }^{7}$ These variations during the postprandial period are responsible for the strikingly different profile of gastric emptying and intestinal flow observed in Zollinger-Ellison patients and normal individuals. In healthy persons (and in patients with idiopathic duodenal ulcer) ${ }^{9}, 10$, duodenal acid and volume loads increase postprandially, peak usually toward the end of the first hour, and then decline. In spite of their higher fasting secretory rate, Zollinger-Ellison patients have lower duodenal loads during the first postprandial hour than during either fasting (when steady-state conditions between gastric secretion and emptying prevail) or the late postprandial period (when the inhibitory effect of the meal on gastric secretion and emptying has disappeared). Nevertheless, even in the late postprandial period, duodenal acid load fluctuates considerably, and some degree of incoordination appears to exist between gastric acid discharges and duodenal neutralising mechanisms.

Can these inhibitory mechanisms of gastric secretion and emptying offer a perceptible protection against intraduodenal disturbances in ZollingerEllison syndrome? Our data suggest that, indeed, this might be the case, as, during the first postprandial hour (when the bulk of the meal was being emptied, as shown in Fig. 1), values for intraluminal dilution, $\mathrm{pH}$, enzymes, and bile acids were relatively normal in most patients, whereas later in the postprandial period, intraduodenal homeostasis was greatly disturbed. Malabsorption is an inconstant clinical feature of the Zollinger-Ellison syndrome, although, admittedly, accurate balance studies are not always performed in a clinical setting. In most reported cases, steatorrhoea is relatively mild ${ }^{1-6}$, and, as I noted in my previous report, ${ }^{7}$ Zollinger-Ellison patients without previous gastric surgery are usually well nourished. It is possible that, in many patients, maldigestion and malabsorption affect only the fraction of the meal that leaves the stomach during the late postprandial period. This hypothesis would be consistent with our data and would explain why steatorrhoea is not more prevalent or severe in patients with Zollinger-Ellison syndrome.

Diarrhoea, on the other hand, might be more common and prominent in Zollinger-Ellison patients, because it depends not only on malabsorption of ingested fat, so-called fatty acid diarrhoea ${ }^{18}$ but also on massive gastric fluid loads to the gut during late postprandial and interdigestive periods. It is recognised that, even in normal individuals, excessive fluid loads may overcome the absorptive capacity of the bowel. ${ }^{19}$ Estimates of maximal water absorption by the human gut oscillate between 10 and $15 \mathrm{ml} / \mathrm{min}^{20}$, and these figures are in the range of jejunal fluid loads measured in patients with Zollinger-Ellison syndrome during the late postprandial period (Fig. 2).

In summary, various interacting mechanisms apparently determine intraduodenal conditions prevailing at a given time after a meal in patients with Zollinger-Ellison syndrome. Several pathophysiological mechanisms and their deleterious effects on digestion have been identified in the past. In this study, we have focused on less well-recognised 'protective mechanisms', which probably help limit the adverse effects of sustained hypergastrinaemia on postprandial gastrointestinal function.

The author thanks Mrs Judith A Duenes, Larry $\mathbf{R}$ Stokes, Ms Brenda A Marben, and Richard Tucker for their technical assistance and Ms Gaurdis Grube for her secretarial help. 


\section{References}

${ }^{1}$ Summerskill WHJ. Malabsorption and jejunal ulceration due to gastric hypersecretion with pancreatic islet-cell hyperplasia. Lancet 1959; 1:120-3.

${ }^{2}$ Deleu J, Tytgat H, Van Goidsenhoven GE. Diarı hea associated with pancreatic islet-cell tumours. Am J Dig Dis 1964;9:97-108.

${ }^{3}$ Singleton JW, Kern F Jr, Waddell WR. Diarrhea and pancreatic islet cell tumor: report of a case with a severe jejunal mucosal lesion. Gastroenterology 1965;49:197208.

${ }^{4}$ Vogel RM, Weinstein LD, Herskovic T, Spiro HM. Mechanisms of steatorrhea in the Zollinger-Ellison syndrome. Ann Intern Med 1967;67:816-22.

${ }^{5}$ Shimoda SS, Saunders DR, Rubin CE. The ZollingerEllison syndrome with steatorrhea. II. The mechanisms of fat and vitamin $\mathrm{B}_{12}$ malabsorption. Gastroenterology $1968 ; 55: 705-23$.

${ }^{6} \mathrm{Go}$ VLW, Poley JR, Hofmann AF, Summerskill WHJ. Disturbances in fat digestion induced by acidic jejunal $\mathrm{pH}$ due to gastric hypersecretion in man. Gastroenterology $1970 ; 58: 638-46$.

${ }^{7}$ Malagelada JR. Pathophysiological responses to meals in the Zollinger-Ellison syndrome: 1. Paradoxical postprandial inhibition of gastric secretion. Gut 1978;19: 284-9.

'Malagelada JR, Go VLW, DiMagno EP, Summerskill WHJ. Interactions between intraluminal bile acids and digestive products on pancreatic and gallbladder function. J Clin Invest 1973;52:2160-5.

'Malagelada JR, Longstreth GF, Summerskill WHJ, Go VLW: Measurement of gastric functions during digestion of ordinary solid meals in man. Gastroenterology 1976 ;70:203-10.

${ }^{10}$ Malagelada JR, Longstreth GF, Deering TB, Summerskil! WHJ, Go VLW. Gastric secretion and emptying after ordinary meals in duodenal ulcer. Gastroenterology 1977;73:989-94.
${ }^{11}$ Longstreth GF, Malagelada JR, Go VLW. The gastric response to a tıanspyloric duodenal tube. Gut 1975;16: 777-80.

${ }^{12}$ DiMagno EP, Go VLW, Summerskill WHJ. Relations between pancreatic enzyme outputs and malabsorption in severe pancreatic insufficiency. $N$ Engl $J$ Med $1973 ; 288: 813-5$.

${ }^{13}$ Donaldson RM Jr, von Eigen PR, Dwight RW. Gastric hypersecretion, peptic ulceration and islet-cell tumor of the pancreas (the Zollinger-Ellison syndrome): report of a case and review of the literature. $N$ Engl J Med 1957;257:965-70.

${ }^{14}$ McCarthy DM, Olinger EJ, May RJ, Long BW, Gardner JD. $\mathrm{H}_{2}$-histamine receptor blocking agents in the Zollinger-Ellison syndrcme: experience in seven cases and implications for long-term therapy. Ann Intern Med 1977;87:668-75.

${ }^{15}$ Dubois A, Van Eerdewegh P, Gardner JD. Gastric emptying and secretion in Zollinger-Ellison syndrome. $J$ Clin Invest 1977;59:255-63.

${ }^{16}$ Clain JE, Malagelada JR, Go VLW, Summeıskill WHJ. Participation of the jejunum and ileum in postprandial gastric secretion in man. Gastroenterology 1977;73:211-4.

${ }^{17}$ Clain JE, Go VLW, Malagelada JR. Inhibitory role of the distal small intestine on the gastric secretory response to meals in man. Gastroenterology 1978;74: 704-7.

${ }^{18}$ Ammon HV, Thomas PJ, Phillips SF. Effects of oleic and ricinoleic acids on net jejunal water and electrolyte movement: perfusion studies in man. $J$ Clin Invest 1974;53:374-9.

${ }^{19}$ Levy AG, Benson JW, Hewlett EL, Herdt JR, Doppman JL, Gordon RS Jr. Saline lavage: a rapid, effective, and acceptable method for cleansing the gastrointestinal tract. Gastroenterology 1976; 70:157-61.

${ }^{20}$ Love AHG, Mitchell TG, Phillips RA. Water and sodium absorption in the human intestine. $J$ Physiol (Lond) $1968 ; 195: 133-40$. 